fury (though Mr. Wallace furnishes a possible analogy to ancient custom in what we may call a sociable Amok), the contagion of fear makes it easily intelligible how even a district might come to see and hear what had no existence save in the disturbed imagina. tion of one. The Incubi and Suscubi of the Middle Ages in Europe may be paralleled at the present day in asylums, and, now as then, are met with among those who have placed themselves in conditions similar to the unhealthy ones of the Convent.

In reading over the confessions of the witches in England and Scotland, it is strange to find how exactly the language employed expresses the frequently described sensations of women labouring under uterine and ovarian disease. Doubtless, not all thus suffered; but the confusion once made and heard would be repeated by the unhappy imbeciles from whom chiefly the witch ranks were recruited.

Glasgow University

\section{The Vervain and Yellow Fever}

Allow me to say a few words on the report of tha English Vice-Consul at Ciudad, Bolivar, concerning the efficacy of the Vervain plant as a remedy for yellow fever and black vomit (NATURE, March 2I, p. 4I2). The plant in question is Stachytarpha jamaicensis, Vahl, a very common and rather troublesome weed, called in Spanish America "Verbena," in the British West Indies "Vervain," and in the Brazils "Gervaô." Its medicinal properties have been greatly exaggerated, though it is certainly somewhat aromatic and astringent; but in yellow fever and black vomit its efficacy is next to nothing. For a good description of the plant and some notes on its supposed and real virtues, I refer to Auguste de St. Hilaire, "Plantes usuelles du Brésil," plate 39 (Paris, 'x824). Another tolerably good figure is given by Sloane, "The Natural History of Jamaica," plate 107, I, who mentions several diseases against which it was used in his times (and probably still), stating finally, that "it is good against charms."

Caracas, Venezuela, May 6

\section{ELECTRIC VALENTINE}

TELEGRAPH CLERK of TO TELEGRAPH CLERK $q$

"THE tendrils of my soul are twined With thine, though many a mile apart;

And thine in close-coiled circuits wind Around the magnet of my heart.

"Constant as Daniell, strong as Grove ; Seething through all its depths, like Smee;

My heart pours forth its tide of love, And all its circuits close in thee.

"O tell me, when along the line From my full heart the message flows,

What currents are induced in thine? One click from thee will end my woes."

Through many an Ohm the Weber flew, And clicked this answer back to me"I am thy Farad, staunch and true, Charged to a Volt with love for thee."

[NOTE BY THE EDITOR-

$\mathrm{Ohm}=$ Standard of resistance.

Weber = Electric current.

Volt = Electromotive force.

Farad = Capacity (of a condenser).

Velocity of Puck, $\frac{\text { Once round the Earth }}{40 \text { minutes. }}$ of Ohm, Quadrant of meridian of Paris

$\therefore \mathrm{IOhm}=600$ Pucks.]
NATURAL SCIENCE AT OXFORD

$\mathrm{T}$ has been resolved in Convocation that the Curators of the University Chest be anthorised to pay to the credit of the Museum Delegates the sum of $1,000 l$., to be employed at their discretion for the maintenance and improvement of the Collections in the Museum; a full statement of the expenditure for these purposes being prepared annually and reported to Convocation.

MAGDALEN COLLEGE.-Demyships and Exhibition.There will be an election at this College in October next to not less than Six Demyships and One Exhibition. Of the Demyships, one at least will be Mathematical, one at least in Natural Science, and the rest. Classical. The Exhibition will be in Mathematics, is of the value of $75 \%$. per annum, inclusive of all allowances, and is tenable for five years.

EXETER COLLEGE - There will be an Election to a Natural Science Fellowship in this College on Wednesday, June 10. The Examination will be in Biology. The Fellow elected will be required to reside and take part in the instruction of the College. The election will take place under the conditions of the following special ordinance of the College :-- "Any Fellow who shall be elected previous to June 1874 , with the declared purpose of taking part as Tutor or Lecturer in the College, shall ipso facto vacate his Fellowship on ceasing to reside. Provided also that if the said Fellow shall have taken part as Tutor or Lecturer in the College for seven academic years, consecutively or not, or for part of the time in one office and part in the other, he shall retain his Fellowship, subject only to the other causes of avoidance of Fellowship. Any fellow so elected shall hold himself bound, on pain of the loss of his Fellowship, to take part, if required, as Tutor or Lecturer in the College. If any such Fellow be incapacitated through ill health for educational work in the College, it shall be competent for two-thirds of the Governing Body, with the sanction of the Visitor, to dispense with the required residence during the continuance of such ill health." The Fellow elected under the ordinance will be subject in all other respects to the Statutes of the College. The Examination will begin on Tuesday, June II, and no person can be admitted as a Candidate who has not passed all the Examinations necessary for the degree of Bachelor of Arts in the University of Oxford, or been incorforated as a graduate in the University.

Second Public Examination.-P lass School.-In pursuance of the statute, the Board of Studies for directing the Examination of Candidates who do not seek Honours at the Second Public Examination, and also the Examination in the Rudiments of Faith and Religion, gives notice that the books and subjects which may be offered in the Easter and Trinity Terms 1874, and until further notice, are-

In Group C.-(I) The Elements of Plane Geometry, including the doctrine of similar triangles. This includes the portion of Geometry treated of in Euclid Books I.-IV., with the definitions of Book V., and such parts of Book VI. as treat of similar triangles. These subjects may be read in any other treatise. The Elements of Trigonometry, including the trigonometrical ratios of the sum of two angles, the solution of plane triangles, the use of logarithms, and the mensuration of plane rectilinear figures. (2.) The Elements of the Mechanics of Solid and Fluid Bodies, including the composition and resolution of forces, centre of gravity, the simple machines and the application of virtual velocities to them, the laws of motion, the laws of falling bodies, the motion of projectiles, the pressure of fluids on surfaces, the equilibrium of floating bodies exclusive of the theory of stability, the methods of determining specific gravities, the laws of elastic fluids, simple hydrostatical and pneumatical machines. (3.) The Elements of Chemistry, with an elementary practical examination. Candidates who intend to offer this 